\title{
Effect of planting method and rose water spray on seed production in onion, (Allium cepa L.)
}

\author{
F.H. Al-Sahaf
}

Department of Horticulture, College of Agriculture, Abu-Ghraib, Baghdad, Iraq.

\begin{abstract}
Onion (Allium cepa L.) plants of Texas Grano 502, Local Red, and Local White cultivars were grown either from seeds in seed-to-seed method or from sets (bulbil with $1.5-2.0 \mathrm{~cm}$ in diameter) in set-to-seed method. The plants were sprayed three times (a week interval) with rose water (contained terpene alcohols) at the stage of opening of 5\% of inflorescence flowers during 1997 and 1998 growing seasons. A wide range of insect species visited the umbels of rose water sprayed plants, mainly honeybee (Apis mellifera L.), blowfly (Caliphora vomitoria L.), and housefly (Musca domestica L.), and spraying vegetative part, inflorescence or whole plant revealed similar attractiveness to the insects. Spraying rose water also extended the touch time of the insects on the umbel from 4.5 seconds for untreated to 11.5 seconds for treated plants resulting in a higher percentage of flower set and lower number of aborted flowers in all tested cultivars. Among the plants part treated, the sprayed inflorescence had higher number of seeds (capsule-1) and higher percentage of seed yield increase $(46.1 \%$ and $43.8 \%$ for Texas Grano 502, 59.5\% and $35.6 \%$ for Local Red, and $64.8 \%$ and $43.1 \%$ for Local White cultivars in 1997 and 1998 seasons respectively). A comparison between planting methods, set-to-seed produced greater seed yields compared to seed-to-seed method in all tested cultivars and may be as high as that produced from mother bulb-toseed method used by other authors. However, cultivars responded to the rose water spray variably and were affected by planting method. Texas Grano 502 plants had highest seed yield (634 and 1207 Kg. ha-1) when vegetative part in the set-to-seed method was sprayed; whereas spraying the inflorescence in the seed-to-seed method had the greatest seed yield. In Local White cultivar, the highest seed yield (410 and $1199 \mathrm{Kg}$. ha-1) was achieved when the inflorescence in the set-to-seed plants was treated, whereas, spraying vegetative part with rose water in the seed-to-seed method produced the highest seed yield (359 and $594 \mathrm{Kg}$. ha-1). Spraying whole plant (1997) or inflorescence (1998) of set-to-seed plants of Local Red had the highest seed yield (890 and 1160 $\mathrm{Kg}$. ha-1 respectively), whereas, in the seed-to-seed method, spraying the vegetative part with rose water produced more seed yield (562 and $\left.502 \mathrm{Kg} \mathrm{ha}^{-1}\right)$.
\end{abstract}

Keywords: Onion, cultivars, seed, yield, rose water.

\section{تألثير شماء الورد ولرقة الزراكة عل النتاج البفرف البطل (Allium cepa L.) فالط سuبن المجله

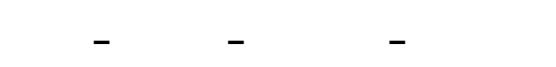

الظلمة : زرعت نباتلت البطل (Allium cepa L.) لأصناف تكسلس كرلنو 502 ، لحمر ولبيض محلي أما بطرية زراعة الذور

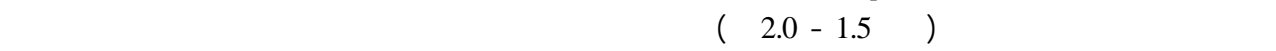

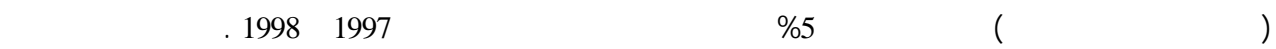

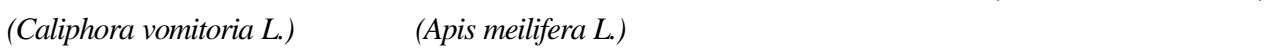

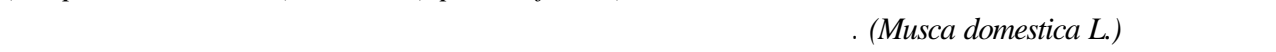

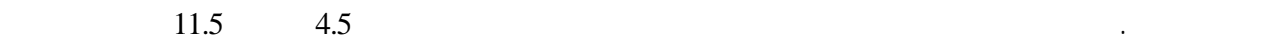

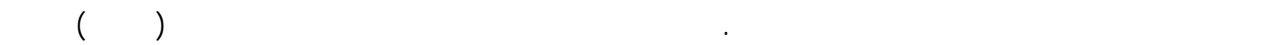

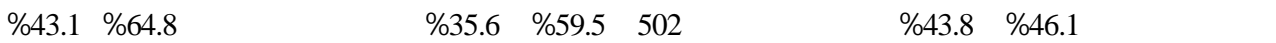

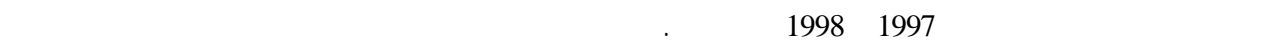

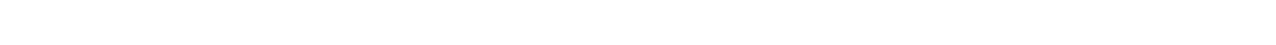

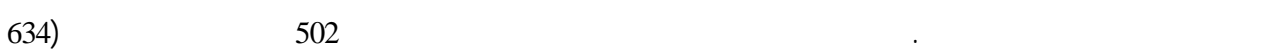

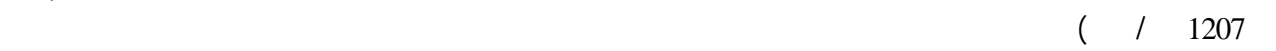

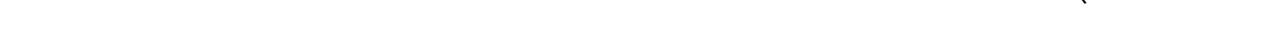

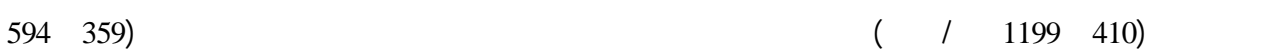

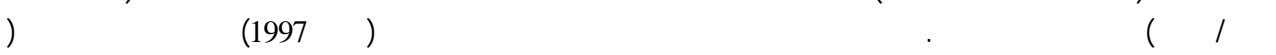

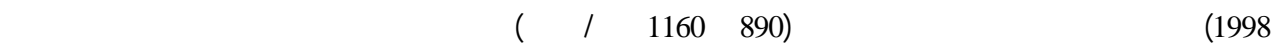
لنباتلت البذور لانتاج البذور أعلت أعلى حالطل بذور (562 و 502كغ / هكتار) للموسمين على التولي.

كالتففتلحية : بصل ، أصنف ، بذور ،ماء الورد . 


\section{Introduction}

Onion (Allium cepa L.) seeds usually are produced by two methods (seed-toseed) and (bulb-to-seed). Each of them has advantages and disadvantages, while higher seed yield and good quality are those achieved from bulb -to-seed method (Ruggeri and Branca, 1994). The onion set is a bulbil with diameter of $1-2 \mathrm{~cm}$ and usually produced by sowing seeds during February, and is harvested in June. Naik and Srinivas (1992) reported that seed production is highly correlated to the mother bulb size.

However' larger bulb size would increase the costs of handling and storage.

The inflorescence in the onion may continue opening for more than two weeks and the plant may bloom for more than 3040 days (Naik and Srinivas, 1992). Cross pollination in onion is dominant, although the flowers are hermaphrodite, and this due to the protandrous nature of onion flowers. The cross pollination is facilitated by insects, where the honeybee and flies play a dominant role. Although a variety of insect species visit onion flowers, still there is a percentage of abortive flowers and this was realized to the lower number of visiting insects that actively perform pollination. Green (1972) found that with onion flowers exposed to housefly (Musca $s p$.) in large cages, the seed yield increased by $60 \%$. Dowker et al. (1985) noticed that honeybee (Apis mellifera L.) activity in pollinating onion flowers is much higher than that of blowflies (Calliphora vomitoria, Lucilia caesar, and L. sericata) under plastic tunnels, and the insect activity differences were attributed to the high temperature inside the tunnel which is not favorable for blowflies forage. Onion flowers were also found to be visited by insects other than Apis $s p$. Those were Trigona spinipes and Pleveia sp., and they actively increased seed yield (Alves et al., 1982).

A number of chemicals have also been used for increasing seed yield, but the most effective growth regulator was $\mathrm{GA}_{3}$.
However, the effect of $\mathrm{GA}_{3}$ on onion seed production is attributed to the increase in the number of inflorescences per plant, and/or syncronization of pistillate and staminate patterns ( Corgan and Montano, 1975). Plant monoterpenes play a very important role in the physiology of insects, which are unable to synthesize them. The monoterpenes are engaged in sex attraction signal in insects. Therefore, the insects have to obtain monoterpenes by feeding on plants (Kumar and Singh, 1993).

The purpose of this study was to examine the effect of rose water (a monoterpenes source) as an insect attracting agent in increasing pollination percentage and seed yield in three onion cultivars using two planting methods for seed production.

\section{Materials and methods}

Rose water treatments

The flowers of Rosa damascena Miller, are gathered in May or June and were subjected to steam distillation. The oil which rises to the top of the distillate is pipetted off, and the water marketed as rose water containing $0.01 \%$ of rose oil. The odor is due to the presence of the terpene alcohols l-citronellol, nerol (which has marked influence on the odor), 1linalool, eugenol and stearoptene (Claus and Tyler, 1967).

Sprays were exogenously introduced on the onion plants using hand sprayer until runoff early in the morning. The plants were at a stage of opening $5 \%$ of the inflorescence flowers. Spraying was repeated three times at one week interval, since the blooming period in onion may last for a month. Spray treatments included whole plant $\left(1350 \mathrm{ml} .18 \mathrm{~m}^{-2}\right)$, vegetative part $\left(1250 \mathrm{ml} .18 \mathrm{~m}^{-2}\right)$, or inflorescence $\left(270 \mathrm{ml} .18 \mathrm{~m}^{-2}\right)$. Precautions were taken to prevent drifting. All treatments contained $0.01 \%$ by volume of "Tween $20 "$ as a 
wetting agent or surfactant (Brewester and Butler, 1989). Control plants were sprayed with distilled water plus the wetting agent.

Plant materials and planting methods

For the seed-to-seed method, seeds of Texas Grano 502, Local Red, and Local White cultivars were sown on $5^{\text {th }}$. September during the years of 1996 and 1997 at the western part of Iraq (Alka'em, elevation 130 m, Lat. 34.3 E, Long $41.0 \mathrm{~N}$, $36.2-23.4^{\circ} \mathrm{C}$, and $27 \%$ R.H.), and the transplants were pricked out on $5^{\text {th }}$. November. For set-to-seed method, set bulbils (of $1.5-2 \mathrm{~cm}$ in diameter) of the above mentioned cultivars were planted on $24^{\text {th }}$. October. Furrows of $90 \mathrm{~cm}$ apart were prepared and transplants (or sets) were spaced $15 \mathrm{~cm}$ within rows (Dowker et al., 1985), and in two rows per furrow in a silt clay loam soil ( $\mathrm{pH}$ equal 7.16). The experiment was designed as a factorial $2 \times 4$ for each cultivar in a randomized complete block design (Steel and Torrie, 1980), and the block consisted of 8 experimental units each of four furrows of $5 \mathrm{~m}$ length.

Usually a plant of seed-to-seed method produced one inflorescence (umbel), and plants of set-to-seed method produced more than one inflorescence, but the first inflorescence is the main one for seed yield and quality (Bacvarov and Rusev, 1969). Accordingly, all umbels other than the first emerged one were removed. Data from each experimental unit were recorded for inflorescence diameter, number of opened flowers $\left(\mathrm{Umbel}^{-1}\right)$, aborted flowers, and seed $\left(\right.$ Capsule $\left.^{-1}\right)$, seed yield of plant, and total seed yield $\left(\mathrm{Kg}\right.$. ha $\left.{ }^{-1}\right)$. Statistical analysis was performed and means were separated according to Duncan's multiple range test at $5 \%$ probability (Duncan, 1955).

\section{Results and discussion}

Insects behavior

The number of visiting insects was counted three days after the introduction of final spray treatments at anthesis stage. One square meter was randomly chosen in the center of plots and replicated four times for each treatment. Data was then recorded on number of visiting insects, type of insect and the total time spent on the umbel (Currah and Ockendon, 1984).

A wide range of insect species was seen to visit onion umbels in the field during the period of blooming. The insects were honeybee (Apis mellifera L.), blowfly (Caliphora vomitoria L.), house fly (Musca domestica L.), oriental hornet (Vespa orientalis ), and others which were not specifically identified.

Data in Table 1 indicate that the foraging activity of the above mentioned insects is adversely correlated to the increased temperature during the day time. The number of insects foraging early in the morning (7.00-10.00 am) and late in the afternoon (5.00-7.30 pm) was greater than those foraging from 10.00 am to $5.00 \mathrm{pm}$ when the day temperature rises drastically. Dowker et al. (1985) recorded similar observations on the adverse effects of high temperatures on the movement and pollination activities of honeybee and blowflies on onion flowers.

The touch time of visiting insects per umbel was recorded during the main periods of activity of the day and comparisons were made between plants sprayed with either rose water or distilled water (control). The visiting insects spent more time moving and foraging on umbel flowers in plants sprayed with rose water (Table 1). These results may indicate the attractiveness of the odorous rose water to the pollinating insects and that may positively increase the number of pollen grains deposited on flowers stigma. 
Table 1. Number of visiting insects during day hours and the effect of rose water spray on touch time per inflorescence in onion

\begin{tabular}{lc}
\hline \multicolumn{1}{c}{ Day hours } & $\begin{array}{c}\text { Number of visiting insects } \\
\text { (insects, } \mathbf{~ m}^{\mathbf{2}} \mathbf{h r} \mathbf{r}^{-1} \text { ) }\end{array}$ \\
\hline $7.0-10.0 \mathrm{am}$ & 16.0 \\
$10.0 \mathrm{am}-5.0 \mathrm{pm}$ & 3.3 \\
$5.0-7.30 \mathrm{pm}$ & 10.8 \\
L. S. D. 0.05 & 2.41 \\
Treatment & Touch time per inflorescence \\
Plants sprayed with rose water & $11.5 \mathrm{~s}$ \\
Plants sprayed with distilled water & $4.5 \mathrm{~s}$ \\
L. S. D. 0.05 & 3.32 \\
\hline
\end{tabular}

Planting method

Plants of set-to-seed method had larger umbel diameter, number of opened flowers $\left(\right.$ umbel $^{-1}$ ), and number of aborted flowers $\left(\right.$ umbel $\left.^{-1}\right)$. The percent increases in the number of opened flowers was for Texas Grano 502 (47.5-139.3 \%), Local Red (90.8-73.3\%), and Local White (68.7-69.3 $\%$ ) for 1997 and 1998 seasons respectively. Although, the number of aborted flowers $\left(\right.$ umbel $^{-1}$ ) in the seed-to-seed method was lower than that of set-to-seed method, the number of opened flowers was lower too in all tested cultivars (Tables 2,3,4). The larger umbel diameter of the set-to-seed method could be the reflection of greater number of opened flowers.

The number of seeds (capsule ${ }^{-1}$ ) produced by set-to-seed flowers was greater than that of seed-to-seed flowers for both seasons and in all tested cultivars, with an exception in one occasion where seed-to-seed flowers had more seeds (capsule $^{-1}$ ). That was in Local Red cv. during 1997 growing season (Table 3). The set-to-seed method also produced the highest seed yield (g.plant ${ }^{-1}$ and Kg.ha ${ }^{-1}$ ) as compared to seed-to-seed method. The percent increase in seed yield of set-toseed as compared to seed-to-seed method were $60.6 \%$ and $187.1 \%$ for Texas Grano $502,70.6 \%$ and $114.6 \%$ for Local Red, and $5 \%$ and $98.3 \%$ for Local White for the two seasons respectively. The seed yield of set-to-seed of Texas Grano 502 ranged from 583 to $107 \mathrm{Kg} \mathrm{ha}^{-1}$, from 778 to 1028 Kg.ha ${ }^{-1}$ for Local Red and from 333 to $1079 \mathrm{Kg} \cdot \mathrm{ha}^{-1}$ for Local White in the two seasons respectively. These figures of seed yield may be as much as those found in Texas Grano 502 using mother bulb-toseed method (Corgan and Montano, 1975, Naamni et al., 1980, Loper and Waller, 1982, and Ruggeri and Branca, 1994). The increase in seed yield, was expected since set-to-seed plants had a larger umbel diameter, greater number of opened flowers, and higher numbers of seeds per capsule. This is in agreement with the results of Naamni et al. (1980) who found that the larger umbels produced more seed yield than smaller umbels.

\section{Effect of rose water spray}

Rose water spray had no significant effect on umbel diameter of Local Red and Local White cvs., whereas umbel diameter of Texas Grano 502 was increased when rose water was sprayed irrespective of plant parts ( Tables 2,3,4). The number of opened flowers was increased in treated plants of Texas Grano 502 and Local Red (1997 only). On the other hand, number of aborted flowers in the three cvs. was reduced by rose water spray. Accordingly, flower set percentage was increased from $73.3 \%$ to $88.0 \%$ in Texas Grano 502, and from $75.9 \%$ to $88.5 \%$ in Local Red when 
the whole plant was sprayed with rose water, whereas the highest percent increase in flower set in Local White (from $74.9 \%$ to $94.0 \%$ ) was when only the vegetative part was treated. The increased number and so increasing the number and touch time of visiting insects touch time of visiting insects of rose water sprayed plants (Table 1) may be expected to increase the flower set percentage in the tested cvs. Monoterpenes of odorous rose water are expected to have an attractive effect on pollinating insects,. 
Table 2. Effect of seed production method and rose water spray on flowering and seed production of onion $\mathrm{cv}$. Texas Early Grano 502 during 1997 and 1998 growing seasons

\begin{tabular}{|c|c|c|c|c|c|c|c|c|c|c|c|c|}
\hline \multirow[t]{2}{*}{ Treatment } & \multicolumn{2}{|c|}{$\begin{array}{l}\text { Inflorescence } \\
\text { diameter }(\mathbf{c m})\end{array}$} & \multicolumn{2}{|c|}{$\begin{array}{c}\begin{array}{c}\text { No. of opened } \\
(\text { inflorescence })^{-1}\end{array} \\
\text { (inflo }\end{array}$} & \multicolumn{2}{|c|}{$\begin{array}{c}\begin{array}{c}\text { No. of aborted } \\
\text { (inflorescence) }^{-1}\end{array}\end{array}$} & \multicolumn{2}{|c|}{$\begin{array}{l}\text { No. of seeds } \\
{\text { (capsule) })^{-1}}^{\text {nat }}\end{array}$} & \multicolumn{2}{|c|}{ Plants seed yield (g) } & \multicolumn{2}{|c|}{$\begin{array}{c}\text { Total seed } \\
\text { production }\left(\mathrm{Kg}^{-h^{-1}}\right)\end{array}$} \\
\hline & 1997 & 1998 & 1997 & 1998 & 1997 & 1998 & 1997 & 1998 & 1997 & 1998 & 1997 & 1998 \\
\hline \multicolumn{13}{|l|}{ Seed- to- Seed } \\
\hline Control & $4.5^{\mathrm{c}^{*}}$ & $4.1^{\mathrm{d}}$ & $135^{\mathrm{d}}$ & $214^{\mathrm{c}}$ & $29^{\mathrm{c}}$ & $67^{\mathrm{ab}}$ & $3.9^{\mathrm{b}}$ & $3.9^{\mathrm{d}}$ & $1.60^{\mathrm{d}}$ & $2.01^{\mathrm{f}}$ & $237^{d}$ & $298^{\mathrm{f}}$ \\
\hline Vegetative & $5.0^{\mathrm{bc}}$ & $4.2^{\mathrm{d}}$ & $139^{\mathrm{d}}$ & $202^{\mathrm{cd}}$ & $16^{\mathrm{d}}$ & $43^{\mathrm{c}}$ & $4.5^{\mathrm{a}}$ & $4.5^{\mathrm{c}}$ & $2.15^{\mathrm{c}}$ & $2.78^{\mathrm{de}}$ & $319^{c}$ & $412^{\mathrm{de}}$ \\
\hline Inflorescence & $5.2^{\mathrm{b}}$ & $4.0^{\mathrm{d}}$ & $185^{\mathrm{c}}$ & $198^{\text {cd }}$ & $15^{\mathrm{d}}$ & $38^{\mathrm{c}}$ & $4.6^{\mathrm{a}}$ & $4.5^{\mathrm{c}}$ & $3.06^{\mathrm{b}}$ & $2.83^{\mathrm{d}}$ & $453^{\mathrm{b}}$ & $419^{d}$ \\
\hline Whole plant & $5.2^{\mathrm{b}}$ & $4.1^{\mathrm{d}}$ & $189^{\mathrm{c}}$ & $189^{\mathrm{d}}$ & $15^{\mathrm{d}}$ & $43^{c}$ & $4.4^{\mathrm{a}}$ & $4.3^{\mathrm{c}}$ & $3.00^{\mathrm{b}}$ & $2.48^{\mathrm{e}}$ & $444^{\mathrm{b}}$ & $367^{\mathrm{e}}$ \\
\hline \multicolumn{13}{|l|}{ Set- to - seed } \\
\hline Control & $5.1^{\mathrm{b}}$ & $6.0^{\mathrm{c}}$ & $226^{\mathrm{b}}$ & $450^{\mathrm{b}}$ & $40^{\mathrm{a}}$ & $73^{\mathrm{a}}$ & $4.3^{\mathrm{a}}$ & $4.0^{\mathrm{d}}$ & $3.25^{\mathrm{b}}$ & $5.33^{\mathrm{c}}$ & $482^{b}$ & $790^{c}$ \\
\hline Vegetive & $6.4^{\mathrm{a}}$ & $6.6^{\mathrm{a}}$ & $258^{\mathrm{a}}$ & $484^{\mathrm{a}}$ & $39^{\mathrm{a}}$ & $62^{\mathrm{b}}$ & $4.5^{\mathrm{a}}$ & $5.4^{\mathrm{a}}$ & $4.28^{\mathrm{a}}$ & $8.15^{\mathrm{a}}$ & $634^{\mathrm{a}}$ & $1207^{\mathrm{a}}$ \\
\hline Inflorescence & $6.3^{\mathrm{a}}$ & $6.2^{\mathrm{bc}}$ & $234^{\mathrm{b}}$ & $490^{\mathrm{a}}$ & $34^{\mathrm{b}}$ & $65^{\mathrm{ab}}$ & $4.7^{\mathrm{a}}$ & $5.2^{\mathrm{ab}}$ & $4.04^{\mathrm{a}}$ & $7.74^{\mathrm{b}}$ & $599^{\mathrm{a}}$ & $1147^{\mathrm{b}}$ \\
\hline \multirow{2}{*}{\multicolumn{13}{|c|}{ Method effect }} \\
\hline & & & & & & & & & & & & \\
\hline Seed- to- Seed & $5.0^{\mathrm{b}}$ & $4.1^{\mathrm{b}}$ & $162^{\mathrm{b}}$ & $201^{\mathrm{b}}$ & $19^{\mathrm{b}}$ & $48^{\mathrm{b}}$ & $4.3^{\mathrm{b}}$ & $4.3^{\mathrm{b}}$ & $2.45^{\mathrm{b}}$ & $2.52^{\mathrm{b}}$ & $363^{\mathrm{b}}$ & $373^{\mathrm{b}}$ \\
\hline Set- to- Seed & $6.0^{\mathrm{a}}$ & $6.3^{\mathrm{a}}$ & $239^{\mathrm{a}}$ & $481^{a}$ & $36^{\mathrm{a}}$ & $66^{\mathrm{a}}$ & $4.5^{\mathrm{a}}$ & $4.9^{\mathrm{a}}$ & $3.94^{\mathrm{a}}$ & $7.23^{\mathrm{a}}$ & $583^{a}$ & $1071 \mathrm{a}$ \\
\hline \multicolumn{13}{|l|}{ Spray effect } \\
\hline Control & $4.8^{\mathrm{b}}$ & $5.0^{\mathrm{c}}$ & $180^{\mathrm{c}}$ & $332^{\mathrm{a}}$ & $35^{\mathrm{a}}$ & $70^{\mathrm{a}}$ & $4.1^{\mathrm{b}}$ & $3.9^{\mathrm{c}}$ & $2.43^{\mathrm{c}}$ & $3.67^{\mathrm{c}}$ & $360^{\mathrm{c}}$ & $544^{\mathrm{b}}$ \\
\hline Vegetive & $5.7^{\mathrm{a}}$ & $5.4^{\mathrm{a}}$ & $199^{\mathrm{b}}$ & $343^{\mathrm{a}}$ & $28^{\mathrm{b}}$ & $53^{\mathrm{b}}$ & $4.5^{\mathrm{a}}$ & $4.9^{\mathrm{a}}$ & $3.21^{\mathrm{b}}$ & $5.46^{\mathrm{a}}$ & $476^{\mathrm{b}}$ & $809^{a}$ \\
\hline Inflorescence & $5.7^{\mathrm{a}}$ & $5.1^{\mathrm{bc}}$ & $209^{\mathrm{ab}}$ & $344^{\mathrm{a}}$ & $25^{\mathrm{c}}$ & $51^{\mathrm{b}}$ & $4.6^{\mathrm{a}}$ & $4.9^{\mathrm{a}}$ & $3.55^{\mathrm{ab}}$ & $5.28^{\mathrm{ab}}$ & $526^{\mathrm{ab}}$ & $782^{a b}$ \\
\hline Whole plant & $5.7^{\mathrm{a}}$ & $5.3^{\mathrm{ab}}$ & $215^{\mathrm{a}}$ & $244^{\mathrm{a}}$ & $23^{\mathrm{c}}$ & $53^{\mathrm{b}}$ & $4.5^{\mathrm{a}}$ & $4.7^{\mathrm{b}}$ & $3.59^{\mathrm{a}}$ & $5.09^{\mathrm{b}}$ & $532^{\mathrm{a}}$ & $754^{a b}$ \\
\hline
\end{tabular}

* Means followed by common letter within the same column do not differ significantly according to Duncans multiple range test at $\mathrm{P}=0.05$. 
Table 3. Effect of seed production method and rose water spray on flowering and seed production onion cv. Local Red during 1997 and 1998 growing seasons

\begin{tabular}{|c|c|c|c|c|c|c|c|c|c|c|c|c|}
\hline \multirow[t]{2}{*}{ Treatment } & \multicolumn{2}{|c|}{$\begin{array}{l}\text { Inflorescence } \\
\text { diameter }(\mathbf{c m})\end{array}$} & \multicolumn{2}{|c|}{$\begin{array}{c}\text { No. of opened } \\
\text { (inflorescence) }^{-1}\end{array}$} & \multicolumn{2}{|c|}{$\begin{array}{l}\text { No. of aborted } \\
\text { (inflorescence) }^{-1}\end{array}$} & \multicolumn{2}{|c|}{$\begin{array}{c}\text { No. of seeds } \\
{\text { (capsule })^{-1}}^{\text {Not }}\end{array}$} & \multicolumn{2}{|c|}{$\begin{array}{c}\text { Plants seed yield } \\
\text { (g) }\end{array}$} & \multicolumn{2}{|c|}{$\begin{array}{c}\text { Total seedd production } \\
\left(\mathrm{Kg}^{-} \mathrm{ha}^{-1}\right)\end{array}$} \\
\hline & 1997 & 1998 & 1997 & 1998 & 1997 & 1998 & 1997 & 1998 & 1997 & 1998 & 1997 & 1998 \\
\hline \multicolumn{13}{|l|}{ Seed- to- Seed } \\
\hline Control & $6.0^{b^{*}}$ & $5.7^{\mathrm{ab}}$ & $127^{\mathrm{e}}$ & $231^{b}$ & $21^{\mathrm{d}}$ & $57^{\mathrm{b}}$ & $4.4^{\mathrm{b}}$ & $4.1^{\text {de }}$ & $1.86^{\mathrm{e}}$ & $2.86^{\mathrm{e}}$ & $276^{\mathrm{e}}$ & $424^{\mathrm{e}}$ \\
\hline Vegetive & $6.0^{\mathrm{b}}$ & $5.5^{\mathrm{b}}$ & $171^{\mathrm{d}}$ & $274^{b}$ & $10^{\mathrm{e}}$ & $38^{\mathrm{d}}$ & $5.2^{\mathrm{a}}$ & $4.2^{\mathrm{d}}$ & $3.48^{\mathrm{cd}}$ & $3.41^{\mathrm{d}}$ & $516^{\mathrm{cd}}$ & $505^{\mathrm{d}}$ \\
\hline Inflorescence & $5.8^{\mathrm{b}}$ & $5.6^{\mathrm{b}}$ & $171^{\mathrm{d}}$ & $271^{b}$ & $12^{\mathrm{e}}$ & $33^{e}$ & $5.7^{\mathrm{a}}$ & $4.2^{\mathrm{d}}$ & $3.79^{c}$ & $3.39^{\mathrm{d}}$ & $562^{\mathrm{c}}$ & $502^{d}$ \\
\hline Whole plant & $6.0^{\mathrm{b}}$ & $5.5^{\mathrm{b}}$ & $144^{\mathrm{e}}$ & $279^{b}$ & $9^{\mathrm{e}}$ & $43^{c}$ & $5.6^{\mathrm{a}}$ & $4.1^{\text {de }}$ & $3.17^{\mathrm{d}}$ & $3.25^{\mathrm{d}}$ & $470^{d}$ & $482^{\mathrm{d}}$ \\
\hline \multicolumn{13}{|l|}{ Set- to - seed } \\
\hline Control & $6.0^{\mathrm{b}}$ & $5.5^{\mathrm{a}}$ & $272^{c}$ & $478^{\mathrm{a}}$ & $44^{\mathrm{a}}$ & $88^{\text {a }}$ & $4.0^{\mathrm{b}}$ & $4.0^{\mathrm{e}}$ & $3.38^{\mathrm{c}}$ & $5.43^{c}$ & $567^{\mathrm{c}}$ & $804^{c}$ \\
\hline Vegetive & $6.0^{\mathrm{a}}$ & $5.9^{\mathrm{a}}$ & $302^{a b}$ & $479^{a}$ & $39^{\mathrm{bc}}$ & $43^{c}$ & $5.3^{\mathrm{a}}$ & $4.7^{\mathrm{c}}$ & $5.87^{\mathrm{a}}$ & $7.14^{\mathrm{b}}$ & $870^{\mathrm{a}}$ & $1058^{b}$ \\
\hline Inflorescence & $6.8^{\mathrm{a}}$ & $5.9^{\mathrm{bc}}$ & $285^{\text {bc }}$ & $481^{\mathrm{a}}$ & $37^{c}$ & $60^{\mathrm{b}}$ & $5.1^{\mathrm{a}}$ & $5.4^{\mathrm{a}}$ & $5.28^{\mathrm{b}}$ & $7.83^{\mathrm{a}}$ & $782^{b}$ & $1160^{\mathrm{a}}$ \\
\hline Whole plant & $6.1^{\mathrm{a}}$ & $5.7^{\mathrm{ab}}$ & $308^{\mathrm{a}}$ & $480^{\mathrm{a}}$ & $43^{a b}$ & $58^{\mathrm{b}}$ & $5.4^{\mathrm{a}}$ & $5.1^{\mathrm{b}}$ & $6.01^{\mathrm{a}}$ & $7.38^{b}$ & $890^{a}$ & $1093^{b}$ \\
\hline \multicolumn{13}{|l|}{ Method effect } \\
\hline Seed- to- Seed & $6.0^{\mathrm{a}}$ & $5.6^{\mathrm{b}}$ & $153^{\mathrm{b}}$ & $277^{\mathrm{b}}$ & $13^{\mathrm{b}}$ & $43^{b}$ & $5.2^{\mathrm{a}}$ & $4.2^{b}$ & $3.08^{b}$ & $3.23^{\mathrm{b}}$ & $456^{\mathrm{b}}$ & $479^{b}$ \\
\hline Set- to- Seed & $6.2^{\mathrm{a}}$ & $5.8^{\mathrm{a}}$ & $292^{\mathrm{a}}$ & $480^{\mathrm{a}}$ & $41^{\mathrm{a}}$ & $62^{a}$ & $5.0^{\mathrm{b}}$ & $4.8^{\mathrm{a}}$ & $5.25^{\mathrm{a}}$ & $6.94^{\mathrm{a}}$ & $778^{a}$ & $1028^{\mathrm{a}}$ \\
\hline \multicolumn{13}{|l|}{ Spray effect } \\
\hline Control & $6.0^{\mathrm{a}}$ & $5.6^{\mathrm{a}}$ & $199^{b}$ & $376^{\mathrm{a}}$ & $32^{\mathrm{a}}$ & $73^{a}$ & $4.2^{\mathrm{b}}$ & $4.1^{\mathrm{c}}$ & $2.85^{b}$ & $4.41^{c}$ & $422^{b}$ & $613^{c}$ \\
\hline Vegetive & $6.0^{\mathrm{a}}$ & $5.7^{\mathrm{a}}$ & $236^{\mathrm{a}}$ & $380^{\mathrm{a}}$ & $25^{b}$ & $41^{\mathrm{d}}$ & $5.3^{\mathrm{a}}$ & $4.5^{b}$ & $4.68^{\mathrm{a}}$ & $5.28^{\mathrm{b}}$ & $693^{\mathrm{a}}$ & $782^{b}$ \\
\hline Inflorescence & $6.3^{\mathrm{a}}$ & $5.7^{\mathrm{a}}$ & $228^{\mathrm{a}}$ & $379^{\mathrm{a}}$ & $24^{\mathrm{b}}$ & $46^{\mathrm{c}}$ & $5.4^{\mathrm{a}}$ & $4.8^{\mathrm{a}}$ & $4.54^{\mathrm{a}}$ & $5.61^{\mathrm{a}}$ & $673^{\mathrm{a}}$ & $831^{\mathrm{a}}$ \\
\hline Whole plant & $6.1^{\mathrm{a}}$ & $5.6^{\mathrm{a}}$ & $226^{\mathrm{a}}$ & $379^{\mathrm{a}}$ & $26^{\mathrm{b}}$ & $51^{\mathrm{b}}$ & $5.5^{\mathrm{a}}$ & $4.6^{\mathrm{b}}$ & $4.59^{\mathrm{a}}$ & $5.32^{\mathrm{b}}$ & $680^{\mathrm{a}}$ & $788^{b}$ \\
\hline
\end{tabular}


Table 4. Effect of seed production method and rose water spray on flowering and seed production of onion cv. Local White during 1997 and 1998 growing seasons.

\begin{tabular}{|c|c|c|c|c|c|c|c|c|c|c|c|c|}
\hline \multirow[t]{2}{*}{ Treatment } & \multicolumn{2}{|c|}{$\begin{array}{l}\text { Inflorescence } \\
\text { diameter }(\mathbf{c m})\end{array}$} & \multicolumn{2}{|c|}{$\begin{array}{c}\begin{array}{c}\text { No. of opened } \\
\text { (inflorescence) }^{-1}\end{array}\end{array}$} & \multicolumn{2}{|c|}{$\begin{array}{c}\text { No. of aborted } \\
\text { (inflorescence) }^{-1}\end{array}$} & \multicolumn{2}{|c|}{$\begin{array}{c}\text { No. of seeds } \\
{\text { (capsule })^{-1}}^{\text {Non }}\end{array}$} & \multicolumn{2}{|c|}{$\begin{array}{c}\text { Plants seed yield } \\
\text { (g) }\end{array}$} & \multicolumn{2}{|c|}{$\begin{array}{c}\text { Total seedd production } \\
\left.\left(\mathrm{Kg}^{-h^{-1}}\right)^{-1}\right)\end{array}$} \\
\hline & 1997 & 1998 & 1997 & 1998 & 1997 & 1998 & 1997 & 1998 & 1997 & 1998 & 1997 & 1998 \\
\hline \multicolumn{13}{|l|}{ Seed- to- Seed } \\
\hline Control & $5.4^{\mathrm{c}^{*}}$ & $5.5^{\mathrm{c}}$ & $127^{\mathrm{b}}$ & $276^{\mathrm{b}}$ & $21^{\mathrm{ab}}$ & $67^{\mathrm{b}}$ & $4.0^{\mathrm{c}}$ & $4.0^{\mathrm{f}}$ & $1.57^{\mathrm{c}}$ & $2.79^{d}$ & $233^{c}$ & $413^{d}$ \\
\hline Vegetive & $6.1^{\mathrm{b}}$ & $5.5^{\mathrm{c}}$ & $137^{\mathrm{b}}$ & $232^{b}$ & $8^{c}$ & $31^{\mathrm{e}}$ & $5.2^{b}$ & $4.3^{c}$ & $2.42^{a b}$ & $4.01^{c}$ & $359^{a b}$ & $594^{\mathrm{c}}$ \\
\hline Inflorescence & $5.8^{\mathrm{bc}}$ & $5.5^{\mathrm{c}}$ & $131^{\mathrm{b}}$ & $278^{b}$ & $8^{c}$ & $28^{\mathrm{e}}$ & $5.3^{\mathrm{b}}$ & $4.1^{\mathrm{de}}$ & $2.35^{\mathrm{b}}$ & $3.87^{c}$ & $348^{\mathrm{b}}$ & $573^{c}$ \\
\hline Whole plant & $5.9^{\mathrm{b}}$ & $5.5^{\mathrm{c}}$ & $129^{b}$ & $284^{\mathrm{b}}$ & $14^{\mathrm{bc}}$ & $30^{\mathrm{e}}$ & $5.3^{\mathrm{b}}$ & $4.2^{\mathrm{cd}}$ & $2.20^{\mathrm{b}}$ & $4.00^{\mathrm{c}}$ & $326^{\mathrm{b}}$ & $593^{c}$ \\
\hline \multicolumn{13}{|l|}{ Set- to - seed } \\
\hline Control & $6.6^{\mathrm{a}}$ & $5.5^{\mathrm{c}}$ & $217^{\mathrm{a}}$ & $464^{\mathrm{a}}$ & $26^{\mathrm{a}}$ & $79^{a}$ & $4.0^{\mathrm{c}}$ & $4.0^{\mathrm{ef}}$ & $1.54^{\mathrm{c}}$ & $5.57^{\mathrm{b}}$ & $228^{c}$ & $825^{b}$ \\
\hline Vegetive & $5.9^{\mathrm{b}}$ & $5.6^{\mathrm{c}}$ & $217^{\mathrm{a}}$ & $459^{a}$ & $12^{\mathrm{c}}$ & $45^{\mathrm{c}}$ & $5.3^{\mathrm{b}}$ & $5.5^{\mathrm{ab}}$ & $2.34^{\mathrm{b}}$ & $7.67^{\mathrm{a}}$ & $347^{\mathrm{b}}$ & $1136^{\mathrm{a}}$ \\
\hline Inflorescence & $5.7^{\mathrm{c}}$ & $5.9^{\mathrm{a}}$ & $229^{a}$ & $469^{a}$ & $14^{\mathrm{bc}}$ & $39^{\mathrm{d}}$ & $5.7^{\mathrm{a}}$ & $5.6^{\mathrm{a}}$ & $2.77^{\mathrm{a}}$ & $8.09^{\mathrm{a}}$ & $410^{\mathrm{a}}$ & $1199^{a}$ \\
\hline Whole plant & $5.8^{\mathrm{bc}}$ & $5.7^{\mathrm{b}}$ & $219^{a}$ & $474^{\mathrm{a}}$ & $10^{\mathrm{c}}$ & $44^{\mathrm{cd}}$ & $5.1^{\mathrm{b}}$ & $5.4^{\mathrm{b}}$ & $2.33^{b}$ & $7.79^{a}$ & $345^{b}$ & $1154^{\mathrm{a}}$ \\
\hline \multicolumn{13}{|l|}{ Method effect } \\
\hline Seed- to- Seed & $5.8^{\mathrm{b}}$ & $5.5^{\mathrm{b}}$ & $131^{\mathrm{b}}$ & $280^{\mathrm{b}}$ & $13^{\mathrm{a}}$ & $39^{\mathrm{b}}$ & $5.0^{\mathrm{a}}$ & $4.2^{b}$ & $2.14^{\mathrm{a}}$ & $3.67^{\mathrm{b}}$ & $317^{\mathrm{a}}$ & $544^{b}$ \\
\hline Set- to- Seed & $6.0^{\mathrm{a}}$ & $5.7^{\mathrm{a}}$ & $221^{\mathrm{a}}$ & $474^{\mathrm{a}}$ & $16^{\mathrm{a}}$ & $54^{\mathrm{a}}$ & $5.1^{\mathrm{a}}$ & $5.1^{\mathrm{a}}$ & $2.25^{\mathrm{a}}$ & $7.28^{\mathrm{a}}$ & $333^{\mathrm{a}}$ & $1079^{\mathrm{a}}$ \\
\hline \multicolumn{13}{|l|}{ Spray effect } \\
\hline Control & $6.0^{\mathrm{a}}$ & $5.5^{\mathrm{c}}$ & $222^{\mathrm{a}}$ & $364^{\mathrm{a}}$ & $23^{a}$ & $73^{a}$ & $4.0^{\mathrm{c}}$ & $4.0^{\mathrm{c}}$ & $1.55^{\mathrm{c}}$ & $4.18^{\mathrm{b}}$ & $230^{c}$ & $619^{\mathrm{b}}$ \\
\hline Vegetive & $6.0^{\mathrm{a}}$ & $5.6^{\mathrm{abc}}$ & $227^{\mathrm{a}}$ & $370^{\mathrm{a}}$ & $10^{\mathrm{b}}$ & $8^{b}$ & $5.3^{\mathrm{b}}$ & $4.9^{\mathrm{a}}$ & $2.38^{a b}$ & $5.84^{\mathrm{a}}$ & $353^{a b}$ & $865^{\mathrm{a}}$ \\
\hline Inflorescence & $5.8^{\mathrm{a}}$ & $5.7^{\mathrm{a}}$ & $231^{\mathrm{a}}$ & $374^{\mathrm{a}}$ & $11^{\mathrm{b}}$ & $33^{\mathrm{c}}$ & $5.5^{\mathrm{a}}$ & $4.9^{\mathrm{a}}$ & $2.56^{\mathrm{a}}$ & $5.98^{\mathrm{a}}$ & $379^{\mathrm{a}}$ & $886^{\mathrm{a}}$ \\
\hline Whole plant & $5.8^{\mathrm{a}}$ & $5.6^{\mathrm{abc}}$ & $224^{\mathrm{a}}$ & $379^{\mathrm{a}}$ & $12^{b}$ & $37^{b c}$ & $5.2^{\mathrm{b}}$ & $4.8^{\mathrm{b}}$ & $2.27^{\mathrm{b}}$ & $5.90^{\mathrm{a}}$ & $336^{\mathrm{b}}$ & $874^{\mathrm{a}}$ \\
\hline
\end{tabular}

* Means followed by common letter within the same column do not differ significantly according to Duncans multiple range test at $\mathrm{P}=0.05$. 
Whether rose water has a synocronising effect on pistillate and staminate patterns in onion flowers similar to that of $\mathrm{GA}_{3}$ has yet to be resolved. Spraying onion plants with $\mathrm{GA}_{3}$ was found to increase flower set due to the synocronization of pistillate and staminate patterns in flowers (Corgan and Montano, 1975, Naamni et al., 1980).

The number of seeds (capsule ${ }^{-1}$ ), plant seed yield (g. plant ${ }^{-1}$ ), and total seed yield (Kg. ha ${ }^{-1}$ responded positively to rose water spray in all tested cvs. The increases in the number of seeds (capsule ${ }^{-1}$ ) probably was due to the increases in the number of pollen grains resulting from intensive foraging of insects (Currah and Ockendon, 1984, Doweker et al., 1985). A comparisons of the treated part of the plants showed that highest seed yield was obtained from the sprayed inflorescence only (Tables 2,3,4). The interactive effect of planting method $\mathrm{X}$ rose water spray was significant, and plants of set-to-seed of Texas Grano 502 when vegetative part was treated only had the highest seed yield in both seasons. Spraying the inflorescence of plants of similar method of planting in Local White cv. produced the highest seed yield when compared to other spray treatments in both seasons. However, Local Red cv. had the highest seed yield when either the whole plant (1997), or the inflorescence (1998) were sprayed with rose water in set-to-seed plants. In seedto-seed method, the highest seed yield was obtained from spraying inflorescence with rose water in Texas Grano 502 and Local Red cvs., while spraying the vegetative part in Local White cv. had the highest yield.

\section{Conclusions}

Onion seed production faces a problems of low flower set due to the protandary nature of the flowers, and little number of pollinating insects that forage and groom on the umbels, since cross pollination in onion flowers is dominant. Rose water spray was used in this experiment in an attempt to increase the number of pollinating insects visiting umbels since this odorous water has an attractive effect on insects. Spraying of rose water on the inflorescence, vegetative part, or whole plant increased the number of visiting insects to the flowers and they spent long periods foraging or grooming on the umbel, so the flower set percent was elevated. However, the increased seed yield due to rose water spray differed according to the plant part sprayed. The fact that the highest yield was obtained when inflorescence was treated in the three cvs. tested suggested lower costs as compared to other spray treatments.

Set-to-seed method showed more seed yield, mainly due to the increased number of opened flowers and higher flower set percentage. The increases in seed production by set-to-seed method may equalize that produced by mother bulb-to-seed method found by other authors. Naamni et al, 1980, suggest the adoption of set-to-seed method for seed production due to the low costs of storage, and it has all the other mother bulbs method advantages

\section{References}

Alves, S. B., J. D. Vedramiu, S. Silveira Neto, and O. Nakano, 1982. Insect pollination of onion, Allium cepa $L$. Solo. 74 (1/2), 18-22.

Bacvarov, S., and D. Rusev, 1969. Studies on some reproductive characteristics in transplantonion variety Liaskovski 58. Grad. Lozar. Nauka., 6 (4), 83-88.

Brewester, J. L., and H. A., Butler, 1989. Inducing flowering in growing plant of over wintered onions: Effect of suplpementary irradiation, photoperiod, 


\section{F. H. Al-Sahaf}

nitrogen, growing medium and gibberellins. J. hort. Sci., 64, 301-312.

Duncan, D. B., 1955. Multiplerange and multiple F-tests. Biometrics, 11,1-48.

Claus, E.P., and V. E. Jr. Tyler, 1967. Parmacognosy. P. 200., Lea and Febiger, Philadelphia, USA.

Corgan, J. N., and T. M. Montano, 1975. Bolting and other responses of onion (Allium cepa L.) to growth regulating chemicals. J. Amer. Soc. Hort. Sci., 100 (3), 273-276.

Currah, L., and D. J. Ockendon, 1984. Pollination activity by blowflies and honeybees on onions in breeders cages. Ann. appl. Biol., 105 (1), 167-176.

Dowker, B. D., L. Currah, J. F. Horobin, J. C Jackson, and G. J. Faulkner, 1985. Seed production of an F1 hybrid onion in polyethylene J. Tunnels, Hort. Sci., 60 (2), 251-256.

Green, J. H., 1972. The influence of bulb size, bulb cutting and separation of axillary shoots on seed production of onion (Allium cepa L.). J. Hort. Sci., 47 (3), 365-368.

Kumar, H. D., and H. N. Singh, 1993. Plant metabolism. P. 259., 2nd. ed., Affiliated East-West Press Private Limited, New Delhi, India.

Loper, G. M., and G. D. Waller, 1982. GA ${ }_{3}^{-}$ increased bolting and seed production in late-planted onions. Hort. Science 17(6), 922-923.

Naamni, F., H. D. Rabinowitch, and N. Kedar, 1980. The effect of GA3 application on flowering and seed production in onion. J.Amer.Soc.Hort.Sci., 105 (2), 164-167.

Naik, L. B., and K. Sirnivas, 1992. Seed production of vegetable crops. II. A review. Agric. Rev., 13(2), 59-80.

Ruggeri, A., and F. Branca, 1994. Sowing date and GA3 in onion seed production. Acta Horticulturae 362, 35-42.

Steel, R. G. D., and J. H. Torrie, 1980. Principles and procedures of statistics. A biometrical approach. 2nd. ed., PP.336376., McGraw-Hill Kogakusha, LTD., Tokyo, Japan 